Marquette University

e-Publications@Marquette

Social and Cultural Sciences Faculty Research and

Publications

Social and Cultural Sciences, Department of

6-1-2016

\title{
Public Assistance of Police during Criminal Investigations: Russian Experience
}

Olga B. Semukhina

Marquette University, olga.semukhina@marquette.edu

Accepted version. Police Practice and Research, Vol. 17, No. 3 (June 2016): 229-248. DOI. (C) 2016

Taylor \& Francis. Used with permission. 


\title{
Public Assistance of Police During Criminal Investigations: Russian Experience
}

\author{
Olga Semukhina \\ Social and Cultural Sciences, Marquette University \\ Milwaukee, WI
}

\begin{abstract}
This study examines the high levels of public unwillingness to assist police in criminal investigations in Russia. Variables of public trust of police, fear of crime, victimization, and prior contact with police are used to explain this phenomenon. Also included in the study are variables of police fear and avoidance of police. The findings suggest that higher levels of distrust in, as well as fear and avoidance of police are strong predictors of citizens' unwillingness to assist police in Russia. The paper discusses potential implications of these findings for the 2011 police reform in Russia.
\end{abstract}

\section{Introduction}

Strong public support and public-police cooperation are key factors in effective social control performed by police in every society. Russia continues to experience serious problems in these areas, lagging significantly behind most western countries (Jackson et al., 2011). Recent survey data suggests that despite numerous reforms in the criminal justice system, many Russians continue to hold negative views of their police and refuse to cooperate with them. According to the data by Levada Center collected in 2013 , only $41 \%$ of citizens are willing to assist the police in investigation (Levada, 2013). The study by WCIOM $^{1}$ in 2012 concludes that only $45 \%$ of Russians will agree to be a witness in a criminal case (WCIOM, 2012b). The low level of 
public willingness to cooperate with police in Russia is briefly discussed in extant scholarship, mostly in descriptive analyses or qualitative studies; to this date, we find no research that provides an empirical quantitative examination into the factors responsible for the lack of public-police cooperation in Russia. The purpose of this study is to understand the root causes of low public-police cooperation during criminal investigations in Russia. More specifically, we are concerned with determining if poor police performance or fear and avoidance of police are responsible for Russian citizens' unwillingness to cooperate with police during criminal investigations.

Russian police went through a tremendous transformation after the breakdown of the Soviet Union in 1991. During 1970s-1980s, Soviet police experienced a period of stability with relatively low crime rates and favorable public views (Semukhina \& Reynolds, 2013). Due to rapid political and economic changes occurring during the perestroika in the 1990s, Russian police found themselves grossly understaffed and underfunded while facing skyrocketing crime rates (Sergevnin \& Kovalyov, 2013). Confronted with such challenges, Russian police officers often resorted to bribery, abuse of power and violence as survival tactics (Gudkov, Dubin, \& Leonova, 2004;

Shepeleva \& Novikova, 2005). It was during the 1990s when levels of public trust and public-police cooperation in Russia plummeted to record low numbers (Gilinskiy, 2000, 2006; Gudkov \& Dubin, 2006; Levada, 2013). During the decade of the 2000s, crimes rates and police funding and personnel stabilized (Sergevnin \& Kovalyov, 2013). Nevertheless, the levels of public-police cooperation remain low today (Semukhina \& Reynolds, 2013).

\section{Theoretical framework}

The criminological theory of process-based policing has been predominantly used in recent literature to explain the issues of publicpolice cooperation. This theory often links public-police cooperation and compliance with the public conception of police legitimacy. Legitimacy is primarily understood as the ability of the police institution to influence the individuals not by the use of power, but because the individuals believe that the authority of police is "proper", and "right" (Tyler, 2006; Tyler \& Huo, 2002). There are two main approaches extant literature utilizes to understand police legitimacy: the instrumental and normative schools of thought (Sunshine \& Tyler, 
2003). The former is a utilitarian approach that emphasizes the "cost" and "benefits" of cooperating with police for the citizens. This approach focuses on associations among police effectiveness, satisfaction with police contact, victimization, fear of crime, and public willingness to cooperate with police (Nagin, 1998; Skogan \& Frydl, 2004). According to the instrumental approach, the conception of police legitimacy and consequently public willingness to cooperate with the police during investigations are based on self-interest, rational decision-making and reasons of prudence and fear of punishment (Bottoms \& Tankebe, 2012). If police effectively deter potential offenders from committing crimes and fairly distribute police services among all citizens, the levels of public-police cooperation remain high (Sunshine \& Tyler, 2003). The instrumental approach advocates increased effectiveness of police performance as the key factor in developing successful publicpolice cooperation; thus, past positive experiences with police are crucial for future public assistance of police with criminal investigation (Skogan \& Frydl, 2004; Tyler et al., 2007). Furthermore, poor police performance demonstrated through high levels of fear of crime, victimization and low satisfaction with police are deemed responsible for the low levels of future public cooperation (Tyler, et al., 2007).

The second school of thought, known as the normative model of police legitimacy, is concerned with the link between procedural justice and public willingness to cooperate with the police. The normative school does not dictate that a simple cost-benefit analysis can explain the public-police relations; rather, it emphasizes that people are moral agents concerned more with issues of "proper" authority than maximizing their benefits and positive outcomes (Reisig, Tankebe, \& Mesko, 2013). The studies on procedural justice assert that a duty to obey police and cooperate with them comes from a greater concept of police legitimacy grounded in public trust of police as an institution and an understanding that the police act in the best interests of the citizenry (Murphy, Hinds, \& Fleming, 2008; Sunshine \& Tyler, 2003). Hence, the police need "to activate feelings of obligation and responsibility for their effectiveness" among citizens in order to achieve high levels of cooperation in criminal investigation (Tyler, 2006 , p. 13; 2013). These feelings are based primarily on shared value consensus and understanding that the police are making decisions fairly and transparently, and that they can be trusted in making the right decisions for the community (Sunshine \& Tyler, 
2003; Tyler \& Huo, 2002). This understanding is grounded in the idea that public trust in the police institution and pertinent public-police cooperation is a social judgment, which is based on the shared sense of morality and is not a simple accumulation of positive past experiences. The normative antecedents of police legitimacy are often linked to studies on community-based policing, a model that is built on the idea of policing by consent (Reisig, 2007). Consent and voluntary compliance are believe to be logical outcomes of fair decision-making by police and perceptions of value consensus between police and citizens (Hinds \& Murphy, 2007; Tyler, 2006; Tyler \& Huo, 2002).

Traditionally, the normative approach to police legitimacy have been favored over the instrumental one in the studies on the processbased model of policing (Hinds \& Murphy, 2007; Reisig, Tankebe, \& Mesko, 2014; Sunshine \& Tyler, 2003). However, recently, there has been an attempt to reconcile both instrumental and normative schools by emphasizing that the two approaches are not mutually exclusive but rather complimentary ideas (Tankebe, 2008, 2013). According to this dialogic approach, police legitimacy is viewed as a complex phenomenon where the police effectiveness mediates the procedural fairness and the police trustworthiness, which at the end leads to the public compliance and cooperation with police (Tankebe, 2008).

Extant studies on public-police cooperation conducted in the United States repeatedly suggest that procedural antecedents of police legitimacy are critical in understanding the phenomenon of publicpolice cooperation. Researchers in the U.S. found that citizens who believe that the police treat them fairly and respectfully were more likely to cooperate with the police regardless of the citizen's socioeconomic status, past experiences with crime, and crime rates in the area (Reisig, 2007; Sunshine \& Tyler, 2003; Tyler, 2013). Studies on public-police cooperation outside the U.S. also conclude that factors of procedural justice (e.g. fairness in decision-making and motive-based trust) are critical in predicting public-police cooperation, however the variables of instrumental legitimacy (e.g. police performance) also play an important role (Hinds \& Murphy, 2007; Murphy, et al., 2008; Reisig \& Lloyd, 2009; Reisig, et al., 2013; Reisig, et al., 2014; Tankebe, 2008).

Our study stems from the findings of both schools and examines whether factors of poor police performance or abuse of power are and permission has been granted for this version to appear in e-Publications@Marquette. Taylor \& Francis (Routledge) does not grant permission for this article to be further copied/distributed or hosted elsewhere without the express permission from Taylor \& Francis (Routledge). 
responsible for the unwillingness of Russian citizens to assist the police in criminal investigations. In this regard, our paper examines factors of procedural justice (trust, fear and avoidance of police) as well as instrumental variables of performance (fear of crime, prior contact with police, and prior victimization) as potential reasons for low publicpolice cooperation in Russia.

\section{Previous studies}

Table 1 around here

Table 1 provides a summary of selected empirical studies on Russian police. Available data suggests that at least $30 \%$ of Russians routinely refuse to report crimes, and less than half of all surveyed residents are willing to assist police in criminal investigation or contact police in life-threatening situations. The majority of Russians believe that the police are uninterested in cooperating (WCIOM, 2012c), and most victims do not report crimes due to their belief that the police are unable to solve them (INDEM ${ }^{2}$, 2007; Public Verdict Fund, 2010). Studies in Table 2 also demonstrate that Russia's records on public trust of police is poor with at least $50 \%$ of Russians refusing to trust the police in any given year. Pervasive distrust of police in Russia is associated with the feeling that the police do not act in the best interest or share the values of the citizenry; between $15 \%$ and $25 \%$ of Russians feel this way in any given year (Gudkov \& Dubin, 2006; Rimskyi, 2012; WCIOM, 2012a).

Both distrust and lack of value consensus between the police and public are coupled with significant levels of police fear in Russia with $25 \%$ to $46 \%$ of Russians reporting to fear police officers (Table 1 ). Whereas in other counties fear of police is experienced primarily by members of marginalized groups, in Russia these feelings are spreading among all groups of the population (FOM $\left.{ }^{3}, 2012 \mathrm{a}\right)$. Fear of police appears to be a natural consequence of perceived and experienced police abuse and avoidance of the police is commonly employed by many Russians to minimize police victimization (Zernova, 2012).

Studies on Russia suggest that between $21 \%$ and $30 \%$ of Russians are victimized every year (Bezaev, 1999; Gilinskiy, 2000; Goriyanov, 1994; Makarova, 2011). Literature also reports that most Russian victims are not satisfied with the results of police contact 
following victimization (Bezaev, 1999; INDEM, 2001; Rimskyi, 2012; Shepeleva \& Novikova, 2005). Research demonstrates that in the past twenty years the majority of Russians experienced significant levels of fear of crime or concerns with crime rates (Gilinskiy, 2000; Shubkin, 1997). Between $40 \%$ and $50 \%$ of Russians reported to fear victimization in the last 10 years (Beck \& Robertson, 2003; Gudkov, et al., 2004; Ivanova \& Shubkin, 2005; Lelekov \& Tyamin, 2005; Savel'ev, 2010; WCIOM, 2012c).

\section{Research hypotheses:}

Based on discussed literature stemming from both the utilitarian and procedural schools, we propose that public unwillingness to cooperate with police during criminal investigation is grounded in either ineffective police performance or fear of police due to abuse of power. The following are the research hypotheses for this study:

1) Public trust of police, 2) fear of police, 3) avoidance of police, 4) fear of crime, 5) victimization, 6) prior police contact, and 7) demographics are related to public-police cooperation in Russia.

\section{Methodology}

The study is based on survey data collected by the author in the Volgograd region, Russia in June 2009 with a sample size of 540 cases. The Volgograd region is one of eighty-six subjects of federation located in Southern Russia with a current population of 2,604,000 residents as of 2013. The population of the Volgograd region consists of $90 \%$ ethnic Russians; $54 \%$ of Volgograd residents practice Orthodox Christianity. There have been 10.5 crimes committed per 1,000 residents in six months of 2012 in Volgograd region (the Russian national average is 8.72) and the crime rates continued to decline by $5 \%$ in 2012 since 2011 and by $25.3 \%$ since $2001 .{ }^{4}$ The Volgograd region also averages $1.9 \%$ in unemployment rate (with nation-wide rate of $2.1 \%$ ) and the structure of population income is similar to the nation-wide structure. ${ }^{5}$

Multistage random sampling technique was utilized in this study. The sampling technique was performed in three stages. At the first stage, administrative districts that most closely represented the study population criteria were selected. This sampling methodology permitted a variation of $+/-1.5$ percent from the calculated and permission has been granted for this version to appear in e-Publications@Marquette. Taylor \& Francis (Routledge) does not grant permission for this article to be further copied/distributed or hosted elsewhere without the express permission from Taylor \& Francis (Routledge). 
proportions for each of the four sampling quota categories (the proportion of the urban/rural population, gender, geographical crime rate, and age). The authors calculated the sampling quotas using official demographic information published by the Russian State Statistical Department. Variables in location of residence, gender, geographical crime rates, and age were used to develop the quota elements. In the second sampling stage, public and private organizations listed in the official government registry of organizations within a specific administrative area were selected. Universities, pension foundations, and unemployment agencies that included students, retired, and unemployed populations, respectively, supplemented the selected organizations. During the third stage, the author selected specific individuals from lists provided by each organization. The individual candidate list was alphabetized, and then the author employed systematic sampling with an interval of 20-25 individuals. No quotas were applied at this stage of selection. Research assistants conducted the surveys of selected individuals face-to-face.

\section{Table 2 around here}

Table 2 provides a comparison between known parameters of the entire Russian population and the Volgograd region. As shown in Table 2, main demographic parameters between the Volgograd region and the Russian Federation population are similar with exception to age and place of residency. The Volgograd region is slightly older, less rural and has a higher level of college-educated individuals. However, these differences are negligible for the purposes of this study; thus, Volgograd region can be used as a first-cut approximation to the entire population of Russia.

The comparison of known parameters of the Russian Federation and the study sample (age, gender, and education) suggests that the population and the study sample demonstrate similar age and gender distribution. However, the sample is overrepresented by the number of college-degree respondents. Thus, it can be suggested that the study sample is somewhat representative of the Volgograd region population and can be used as a rough approximation for the entire population of Russia. 
The analysis of sample proceeded in two major stages. First, seven hypotheses were derived from the process-based model of policing. Secondly, the hypotheses were tested using the multiple binominal logistic regressions due to the ordinal nature of the main dependent variable of the study (O'Connell, 2006).

The primary dependent variable of this study, "willingness to assist police in criminal investigation," was measured by asking the following question: "Would you be willing to assist the police during a criminal investigation?" Previous research employs similar measurements to examine public-police cooperation in Russia and reports strong measurement validity (Bezaev, 1999; FOM, 2012b; Makarova, 2011). The independent variables included trust of police, fear of police, fear of crime, prior victimization, prior police contact and avoidance of police. The motive-based trust in police has been measured through the question of whether or not "the police can be trusted to make decisions that are right for [the respondent's] community". This measurement is frequently used by other researchers of process-based model of police (Reisig, Bratton, \& Gertz, 2007) and is consistent with Russian-based studies on the public trust of police (Gudkov, et al., 2004). The fear of crime variable is measured through a traditional question on whether the respondent feels safe being out alone in their neighborhood at night. The question has been previously validated in various studies on fear of crime (Ho \& McKean, 2004). Victimization is measured through a self-report within the last three years (Have you been a victim of a crime in the last 3 years?"). Fear of police is measured by asking if the respondent feels fear when he/she sees an approaching police officer. The reputable Russianbased survey center of LEVADA used same measurement for studies on public fear of police (Gudkov, et al., 2004). ${ }^{6}$ Avoidance of police is measured by asking to agree with the statement "It is better to avoid police even when you don't break the law". Similar question was used by LEVADA center to measure avoidance of police and demonstrated strong measurement validity (Gudkov \& Dubin, 2006; Gudkov, et al., 2004). A multi-item scale is preferable over the single variables used in this study, but such a measurement instrument was not possible due to the limitations on the survey length. ${ }^{7}$ 


\section{Findings}

\section{Descriptive statistics}

Table 3 around here

Tables 3-5 provide a cross-sectional frequency analysis of main variables in the study (public-police cooperation, public fear and avoidance of police, trust of police, victimization and contact with police) and the sample's demographics (age, gender, education, income, and occupation). According to Table 3, only $27.6 \%$ of respondents feel it is safe to assist the Russian police in criminal investigation and $49.9 \%$ feels it is not. While all categories of the sample have predominately negative feelings about public-police cooperation, some are more critical of police than others. There are much more respondents who feel unsafe about cooperating with police among older and female respondents. Retired individuals are also more likely to fear assisting the police, whereas industry employees are less likely. Those with lower monthly income (under 7K) ${ }^{8}$ are also more fearful of cooperating with police than those with higher monthly income (18K and higher).

Table 3 also demonstrates that an overwhelming number of Russians (74\%) experience fear when they see an approaching police officer. Only $6.9 \%$ of citizens don't feel this way in our sample. As with the public-police cooperation, older groups of the population are more affected by the fear of police than younger respondents are. Males and females are equally fearful of police officers, even though there are more males who have never experienced fear of an approaching police officer. Fear of police is represented in all categories of Russians with various occupations and levels of monthly income.

\section{Table 4 around here}

Based on Table 4, the majority of Russians (60.2\%) prefer to avoid the police under any circumstances. Only $18.9 \%$ did not adopt such a defensive mechanism. Similar to public-police cooperation and fear of police, older Russians and females are more likely to avoid the

Police Practice and Research, Vol. 17, No. 3 (June 2016): pg. 229-248. DOI. This article is (C) Taylor \& Francis (Routledge) and permission has been granted for this version to appear in e-Publications@Marquette. Taylor \& Francis (Routledge) does not grant permission for this article to be further copied/distributed or hosted elsewhere without the express permission from Taylor \& Francis (Routledge). 
police than younger groups and males. Retired and college-educated individuals are more likely to avoid the police. All income groups and various types of occupation are equally affected by police avoidance.

Table 4 also reveals some interesting findings. Although most Russians fear, avoid and refuse to cooperate with police, a large group of Russians (44.6\%) feels protected from crime by their local police, and only a small number of respondents (16.7\%) do not feel protected. Older Russians (51 and older), females in general and retired respondents appear to feel less protected than those under the age of 30. In addition, females in general and retired respondents are less likely to feel protected from crime by police. Russians earning high-income ( $18 \mathrm{~K}$ and over) seems to feel more protected than lowincome individuals (under 7K). When comparing the findings from Table 4 with Table 3, it can be noted that more Russians are afraid of the police $(74 \%)$ than of the crimes committed against them $(16.7 \%)$.

\section{Table 5 around here}

Based on Table 5, a large number of Russians does not trust the police (46.6\%). As with the previous findings in Tables 3 and 4, older individuals (over 51 years old), females and retired respondents are less likely to trust the police. Younger Russians (under 30 years old), males, and office employees appear to show higher degrees of confidence in their police. Similar to findings in Table 4, higher income groups (over $18 \mathrm{~K}$ of monthly income) are more likely to trust the police, than lower income groups (under 7K a month).

Table 5 also reports on both the contact with police and victimization over the year prior to response. At least a quarter of Russians (24\%) were victimized in the year prior to the survey and $40.3 \%$ had a contact with the police during the same period. It is known from the literature that between $30 \%$ and $50 \%$ of all crimes are reported to the police by victims. This suggests that a significant number of police contacts in our study are either initiated by police and are involuntary (arrests of defendants or subpoenas of witnesses) or are related to the routine work of police unrelated to crime (citizen registration and issuance of licenses). Contrary to the findings from Tables 3 and 4, older respondents (over 51 years old) are less likely to 
contact the police and become the victims of a crime. While females are more likely to contact the police, they are less likely to be victimized, which suggests that their contacts with police were mostly unrelated to crime. Small business owners and unemployed individuals are also more likely to contact the police and claim victimization. Respondents with various levels of income are equally represented among those who contacted the police and claimed victimization.

\section{Hypotheses testing}

Table 6 around here

Table 6 reports the results of binary logistic regression analysis for the dependent variable of opinion on public-police cooperation. The dependent variable is aggregated into two binary categories for this analysis. Only research hypotheses $1,2,3$ and 5 of this study are fully supported and research hypothesis 7 is partially supported.

The significant predictors of odd ratio for public unwillingness to cooperate with police during criminal investigations include fear of crime, fear of police, police violence, distrust of police, prior victimization, and income. None of the other demographic variables (age, gender, occupation, and level of education) are significantly correlated with the public-police cooperation variable. Even more interesting, the variables of police effectiveness in protecting citizens against crime, and contact with police are also non-significant in our research model. The overall percentage of cases predicted through our model is $74.2 \%$, which is increased by $7.8 \%$ when compared to the null model.

\section{Limitations, discussion, and implications}

Several important limitations of this study must be noted. First, the study sample is not fully representative of the Russian Federation; thus, generalizations to the entire country warrant some caution. The sample is overrepresentative of respondents living in large cities, as well as respondents with college degrees. Russia also has large regional heterogeneity, so the Volgograd region does not fully represent Russia's population diversity. Regions with large ethnic minorities (i.e. North Caucuses, Tatarstan, and Bashkortostan) and large metropolitan cities like Moscow and St. Petersburg may have 
significant variations in demographics that can influence public-police cooperation and views of police.

Secondly, the cross-tabulation statistics from Tables 3-5 should be used only as preliminary descriptive findings. Since some of the data distribution in the cells was skewed and not all the cells reached a required minimum, we were unable to use non-parametric statistics to assess the significance of these findings.

The major conclusion of this study is not very surprising: lowincome respondents that fear, distrust and avoid police are less likely to cooperate with the police in criminal investigation because they consider assistance to be risky. Surprisingly, prior contacts with police and perceived police effectiveness do not have statistically significant correlations with cooperating during criminal investigation. Moreover, nearly half of Russian citizens feels protected by their local police $(44.6 \%)$, yet nearly the same proportion (49.9\%) think it is dangerous to assist the police in criminal investigation. The most plausible explanation of this paradox is that the danger of assisting police in Russia comes not from the criminal offenders, but rather from the police themselves. In our study, only $16.7 \%$ reported to feel unprotected from crime, while the overwhelming majority $74 \%$ stated they were afraid of police officers.

Existing literature and examples from human rights organizations support this proposition. Police officers in Russia are among the top violators of human rights and appear to be routinely involved in both torture and corruption (Amnesty International, 2002; Chistye Ruki (Clean Hands), 2012; Committee against Torture, 2006; Human Rights Watch, 1999; Public Verdict Fund, 2012). Literature suggests that abuse from police inflict fear and consequentially police avoidance and non-cooperation among all groups of the Russian population.

Based on our findings, the instrumental approach to police legitimacy only partially explains the low levels of public-police cooperation in Russia; neither police effectiveness nor prior police contact have statistically significant correlations with public cooperation with police. It appears that citizens refuse to cooperate with Russian police not because the "cost" of cooperation is too high compared to the "benefits" (i.e. police effectiveness in crime control is and permission has been granted for this version to appear in e-Publications@Marquette. Taylor \& Francis (Routledge) does not grant permission for this article to be further copied/distributed or hosted elsewhere without the express permission from Taylor \& Francis (Routledge). 
too low when compared to the time and resources spent to cooperate). In other words, the lack of police legitimacy in Russia comes not from the substandard police performance to investigate the crimes, but from an understanding that Russian police act in their self-interest. In such a case, citizens deem future assistance of police unnecessary since the police are perceived as uninterested in protecting the public. However, the factors of police performance should not be disregarded completely since variables of prior victimization and fear of crime appear to be significant in our model.

The procedural justice approach appears to better explain the phenomenon of Russian non-cooperation during criminal investigation. Fear of victimization by the police themselves drastically undermines images of police fairness and legitimacy in the eyes of Russian citizens. These feelings are the foundation of public cooperation with police according to the procedural justice approach (Sunshine \& Tyler, 2003). Logically, voluntarily assisting the police increases the probability of being victimized by the police from the simple fact of increased interaction with them. Avoidance of police in such a case is viewed as logical adaptive practice developed in the presence of the clear danger to become a victim of police abuse.

The statistically significant correlation between the motivebased distrust of police and public-police non-cooperation in our study supports this explanation since trust in police is the main characteristic of police legitimacy in the procedural justice approach. Lack of motivebased trust reinforces the image of Russian police as a self-serving agency, where the public views most criminal investigations as tools for personal gain by police officers rather than enforcement of law and order for greater social interest. Understandably, such views deter future cooperation with police by the citizenry.

If abuse of power by the police is indeed the main culprit of public non-cooperation with police in Russia, it is important to understand the source of knowledge about such police practices. Do such public views come from first-hand experiences or secondary knowledge? Our study suggests that at least some of these views are based on projections by news and entertainment media and other sources of communication. In our study, older and retired individuals were consistently found to have higher levels of fear, avoidance, distrust of and non-cooperation with the police. Yet, these respondents and permission has been granted for this version to appear in e-Publications@Marquette. Taylor \& Francis (Routledge) does not grant permission for this article to be further copied/distributed or hosted elsewhere without the express permission from Taylor \& Francis (Routledge). 
were the least likely to be the victims of the crime or to contact the police, suggesting that their fears came from sources beyond experience. Extant literature on experienced police abuse also supports this proposition since only a small number of Russians reported to be victimized by police, yet the majority fear the police abuse (Public Verdict Fund, 2012).

Findings from this study are consistent with previous research on public-police cooperation conducted in other countries. Variables of procedural fairness play an important role in our understanding of the low levels of public cooperation with police during criminal investigation, whereas the factors of police performance have only a limited role in explaining the unwillingness of Russians to assist the police. Similar findings have been found in study samples of the U.S., Australia and Slovenia (Hinds \& Murphy, 2007; Reisig, 2007; Reisig, et al., 2013; Sunshine \& Tyler, 2003).

Also consistent with research conducted outside U.S. (Tankebe, 2008), our study found little difference in levels of public-police cooperation among various demographic groups. None of the demographic variables (age, gender, education, and occupation) with the exception of income had statistically significant effects on levels of public willingness to assist police in our model. Previous research suggests that such findings are typical of countries where the police face crises of legitimacy and no demographic group offers full support of the police (Tankebe, 2008). In this regard, our findings support the proposition by Gerber, et al., who suggest that Russian police practice represents an example of predatory policing, where the police officers "prey on their society by using their positions to extract direct payment in the form of money, goods, or services from individual members of the public" (Gerber \& Mendelson, 2008, p. 5). This policing model is different from a model of divided society policing, where the police in the interests of dominant elite groups systematically oppress marginalized groups of the population (the poor, ethnic minorities, and political opposition). The high levels of police fear and avoidance reported in this paper are also consistent with the predatory model of policing in which law enforcement practices are used for the self-interest of police officers rather than to build a consent-based policing model.

Police Practice and Research, Vol. 17, No. 3 (June 2016): pg. 229-248. DOI. This article is @ Taylor \& Francis (Routledge) and permission has been granted for this version to appear in e-Publications@Marquette. Taylor \& Francis (Routledge) does not grant permission for this article to be further copied/distributed or hosted elsewhere without the express permission from Taylor \& Francis (Routledge). 
The conclusions of this paper provide strong support for the procedural theory of police legitimacy, which suggests that fair decision-making and social judgment about trustworthiness of police officers are important antecedents of public-police cooperation. Though police effectiveness in crime control and fair distribution of police services should not be disregarded completely, they clearly play secondary roles in our explanatory model. In this regard, our paper advances a theoretical understanding of Russian policing since previous studies offered only descriptive data on the lack of publicpolice cooperation. Findings of this paper are also consistent with previous studies on Russian police, but this paper takes our understanding further by offering empirical evidence that public-police cooperation in Russia is dependent on factors of distrust and fear of police and consequential avoidance of them.

Findings from this study also have important practical implications for the ongoing police reform in Russia. The 2011 reforms consisted of several important measures including raises in wages and benefit of police officers, review of personnel files for all police officers (pereattestatsiya), consolidation of police funding under the federal budget, $20 \%$ personnel cuts, and development of better police assessment and reporting systems (Beck, 2013). Whereas most of the recent government efforts were focused on improving the effectiveness of crime control (Gall, 2011), the findings of this paper suggest that improved police performance may not directly translate into public willingness to cooperate with police during criminal investigation. From our research model, it appears that overcoming the public fear and avoidance of police and building public trust of police should be the priority of future police reform in Russia.

One of the major issues that needs to be addressed in this regard is growing alienation between Russian citizens and police officers. Findings from other post-Soviet countries recommend that increased accountability and transparency of major law enforcement decisions are needed to create a value consensus and societal trust that the police act in the best interests of the citizenry and not preying on citizens for personal benefit (Beck, 2013; Light, 2013). Experiences of other post-Soviet countries suggest that bridging the gap between the public and police is a long-term process that may require drastic 
measures and significant government resources (Kakachia \& O'Shea, 2012).

The issue of effective public accountability necessarily relates to the question of better enforcement of laws against police corruption and torture. Currently, the majority of bribery and corruption cases among police officers remain uninvestigated; the few police officers who are prosecuted often receive minimal penalties (Semukhina \& Reynolds, 2013). At this point, it is unclear whether there is a political will in Russia to change the current situation of predatory policing and to build consent-based policing used in other developed countries. Taylor in his analysis of Putin's presidency suggests that Russian law enforcement agencies in general and the current efforts to reform them have been successfully used to develop the capacity of Russian state-building but intentionally failed to achieve any quality of state offered services. If the analysis by Taylor is accurate, the current 2011 reforms of Russian law enforcement agencies are made primarily to strengthen the capacity of Russian state (Taylor, 2011). In such a case, success of future police reforms in Russia remains questionable.

Though Russian police are almost universally viewed as ineffective, another measure required to build an effective publicpolice cooperation is media coverage aimed at breaking stereotypical images of Russian police force. Current relationships between the media and Russian police are often based on the outdated Soviet strategy to conceal any information from the media or to provide very limited access to any information on the cases of police abuse. As a result, media is often left with speculation, rumors and other unreliable sources when covering a story of police abuse. In the atmosphere of great distrust of police in Russian society, these media speculations paint a predominately negative image of policemen and play an important role in shaping the image of abusive police officers in Russia (Bondarenko, 2006). Female, older, and retired respondents are among the most frequent consumers of TV media content (MacFadyen, 2008), which may explain their elevated fears of police and unwillingness to assist police in criminal investigation despite the lack of victimization or direct police contact found in this study.

The situation is now becoming even more serious with the development of social media and accessibility of the internet in Russia. Young and college-educated Russians are among frequent internet

Police Practice and Research, Vol. 17, No. 3 (June 2016): pg. 229-248. DOI. This article is @ Taylor \& Francis (Routledge) and permission has been granted for this version to appear in e-Publications@Marquette. Taylor \& Francis (Routledge) does not grant permission for this article to be further copied/distributed or hosted elsewhere without the express permission from Taylor \& Francis (Routledge). 
users and consumers of social media content. This content is very critical to police reputation, but is often based on unverifiable sources (Etling et al., 2010). Several researchers suggest that negative views of police by younger generations are often prompted by internet media content rather than first-hand experiences (Bondarenko, 2006; Etling, et al., 2010; Mazaev, 2004). Police violence, torture and exposé from former police officers became a normal part of Russian internet landscape in the last five years (Chistyakova \& Robertson, 2012). Thus, the Ministry of Interior Affairs is in dire need for a new media strategy in which timely information and a friendly environment for dialogue are provided to the public.

Finally, there is also a need to revise the assessment and promotion system for police officers. Currently existing system measures primarily crime rates and other factors of police efficiency (Brailovskaya, 2011). Findings from this study suggest that improved police performance alone is unlikely to cause better public-police cooperation. Instead, the system of assessment should incorporate indicators of public views on police including assessment of each police contact and independent surveys of public opinions. In the current assessment system, such indicators are only used as supplementary measurements and they public views surveys are often conducted by sociological organizations selected by the police themselves (Khabarov, 2011).

This study is only a preliminary attempt to explore the issues of public-police cooperation in Russia. More research is necessary to fully understand the factors influencing public fear and avoidance of police. Future research should consider a fully representative sample of the Russian Federation to account for regional differences in public views of police. Another suggestion for future research is to test a full set of variables on procedural fairness of police (previously developed by Tyler (2002)) in Russian context. Such research will allow for a valid comparison of public-police cooperation in Russia with the U.S. and other countries. The use of multi-item scales by Tyler also provides for better measurement and constructs validity. Other measures of publicpolice cooperation should also be tested including the sense of obligation to obey police officers, as well as actual crime reporting behavior. It would also be beneficial to look at the role of media in shaping these public views and to examine the role of police reform on and permission has been granted for this version to appear in e-Publications@Marquette. Taylor \& Francis (Routledge) does not grant permission for this article to be further copied/distributed or hosted elsewhere without the express permission from Taylor \& Francis (Routledge). 
the public perceptions of the police institution. Finally, it would be illuminating to understand how ethnic minorities, especially labor immigrants, perceive cooperation with Russian police and to what extent their views of the police are different from the general population.

\section{Conclusion}

The purpose of this research paper was to look at the root causes of the low levels of public-police cooperation in Russia over the past two decades. This study reveals that variables of public trust in police, fear of police and police avoidance are important predictors of future public-police cooperation during criminal investigations in Russia. On the other hand, police effectiveness and prior police contact are not significant when predicting public willingness to assist Russian police. These findings are consistent with the process-based model of policing which informed this research.

The study suggests that indicators of police performance do not play an important role in predicting future public cooperation in Russia. We conclude that the current low levels of public willingness to assist Russian police are mainly caused by the crisis of police legitimacy due to the lack of transparency of police decisions and as well as a lack of trust that the police act in the best interests of the citizenry. This conclusion is consistent with the predatory model of policing described by Gerber et al (2008) when police use their authority for self-serving purposes and not for protection of citizenry.

Important lessons can be learned from this study regarding future police reforms in Russia. While it is still important to improve crime control efficiency of Russian police, the future changes should be focused on building better public-police relations and strengthening the public image of Russian police. New mechanisms need to be developed for better police accountability and prevention of police corruption and abuse of power. Such measures include but are not limited to further decentralization and demilitarization of police forces, election of local police officials, transparency of major decision-making through public hearings, and revisions of assessment and promotion system. Results of police reforms in other post-Soviet countries suggest that improvement within post-Soviet police institutions is a long-term process, which requires commitment of both power agents and 
members of civil society. Police reform in Russia therefore must to be done in conjunction with transformation in other criminal justice institutions, especially the court system. (Zernova, 2012).

\section{About the Author:}

Dr. Semukhina is currently an assistant professor of criminology and law studies at Marquette University. Dr. Semukhina holds LLB/LLM degrees from Tomsk State University (Russia) and MS/PhD degrees in criminal justice from University of Central Florida. Dr. Semukhina is a former defense attorney in Russia and a former assistant professor of criminal law and procedure at Tomsk State University. She received multiple grants from Ford and Soros Foundation, Open Society Institute, IREX and U.S. State Department to conduct research and sustain the development of legal services in Russia.

Acknowledgements: The author is grateful for assistance provided by Dr. Demidov in preparation of this paper

\section{References}

Amnesty International. (2002). The Russian Federation. Denial of Justice Available from www.amnesty.org

Beck, A. (2013). Police reform and building justice in Russia. In K. Goodall, M. Malloch \& B. Munro (Eds.), Building Justice in Post-Transition Europe? (pp. 158-175). London and New York: Routledge.

Beck, A., \& Robertson, A. (2003). Crime in Russia: Exploring the link between victimization and concern about crime. International Journal of Crime Prevention and Community Safety, 5(1), 27-46.

Bezaev, M. N. (1999). Obschestvennoe mnenie o kriminogennoi obstanovke i deyatel'nosti vnutrennih del [Public opinion about the criminal conditions and the work of police]. Social Research, 12, 100-105.

Bondarenko, T. A. (2006). Stereootip vospiytiya pravoohranitelnyh organiv na Dal'nem Vostoke [The stereotype about the law enforcement activities in Far East Region]. Social Research, 1, 99-102.

Bottoms, A., \& Tankebe, J. (2012). Beyond procedural justice: A dialogic approach to legitimacy in criminal justice. Journal of Criminal Law and Criminology, 102, 119-170.

Brailovskaya, K. (2011). Kommentarii k prikazu MVD ot 26 dekabrya 2011 \# 1310 [Commentary on Decree of MVD issued on 12.26.2011 \# 1310]. Bulletin of Fund of Public Verdict, 2(11), 27-30.

Chistyakova, Y., \& Robertson, A. (2012). Youtube Cops and Power Without Limits : Understanding Police Violence in 21st Century Russia. Journal of Power Institutions in post-Soviet Societies, 13.

Chistye Ruki (Clean Hands). (2012). Doklad Politistia v zakone [Report. Police in law]. Retrieved from http://www.rusadvocat.com/node

Police Practice and Research, Vol. 17, No. 3 (June 2016): pg. 229-248. DOI. This article is @ Taylor \& Francis (Routledge) and permission has been granted for this version to appear in e-Publications@Marquette. Taylor \& Francis (Routledge) does not grant permission for this article to be further copied/distributed or hosted elsewhere without the express permission from Taylor \& Francis (Routledge). 
Committee against Torture. (2006). Sotsiologiya nasiliya. Proizvol pravookranitelnykh organov glazami grazhdan [Sociology of violence. Police abuse in the eyes of citizens] Available from www.pytkam.net

Egoryshev, S. V. (1997). Organy vnutrennih del kak sotsial'naya organisatsiya: problemy ih reformirovaniya i povysheniya effectivnosti deyatel'nosti [The agencies of Interior Affairs as a social organization: the problems of their reforming and improving the effectiveness of their activity]. Bashkir State University, Ufa.

Ermolaev , V. V., \& Verem'eva, E. A. (2007). K problrme izucheniya organizatsionnoi kultury i imidga militsii [The problem of organizational culture and the image of police]. Bulletin of the Voronezh Institute of MVD, 2, 85-87.

Etling, B., Alexanyan, K., Kelly, J., Faris, R., Palfrey, J., \& Berkman, U. G. (2010). Public Discourse in the Russian Blogosphere: Mapping RuNet Politics and Mobilization. Retrieved 5.5.11, from http://cyber.law.harvard.edu/sites/cyber.law.harvard.edu/files/Public Discourse in the Russian Blogosphere 2010.pdf

FOM. (1997). Chetvertaya chast Rossiyan botisya tekh kto ikh dolzhen zaschishat [The quarter of Russians are afraid of those who should be protecting them]. Retrieved 06.23.2011, from http://bd.fom.ru/report/cat/power/pow I/of19974205

FOM. (2012a). Bezzakonie v politsii [Lawfulness among police]. Retrieved 1.4.2013, from http://fom.ru/Bezopasnost-i-pravo/10377

FOM. (2012b). Issledovanie obschestvennogo mneniya ob urovne bezopasnosti lichnosti i deyatelnosti organov vnutrennokh del [Research on public opinion of public safety and work of police]. Retrieved 9.10.13, from http://vnii-mvd.ru/node/1860

Gall, C. (2011). Das neue russische Polizeigesetz. Russland-analysen, 219, 24.

Gerber, T. P., \& Mendelson, S. E. (2008). Public Experiences of Police Violence and Corruption in Contemporary Russia: A Case of Predatory Policing? Law \& Society Review, 42(1), 1-44.

Gilinskiy, Y. (2000). Challenges of Policing Democracies: The Russian Experience. In D. K. Kas \& O. Marenin (Eds.), Challengers of Policing Democracies. A World Perspective (pp. 173-194). Netherlands: Gordon and Breach Publishers.

Gilinskiy, Y. (2006). Proizvol pravookhranitelnykh organov glazami grazhdan [Police abuse in the eyes of public]. Nizhniy Novgorod: Committee against torsture.

Goriyanov, K. K. (1994). Latent crime in Russia. Moscow: UNICRI, United Nations.

Police Practice and Research, Vol. 17, No. 3 (June 2016): pg. 229-248. DOI. This article is (C) Taylor \& Francis (Routledge) and permission has been granted for this version to appear in e-Publications@Marquette. Taylor \& Francis (Routledge) does not grant permission for this article to be further copied/distributed or hosted elsewhere without the express permission from Taylor \& Francis (Routledge). 
Gryaznova, O. (2006). Otnoshenie zschitelei Rossii k pravoohranitel'nym organam [The attitude of Russian residents toward the law enforcement agencies]. Bulletin of Public Opinion, 2(82), 32-46.

Gudkov, L., \& Dubin, B. (2006). Privatisatsiya politsii [Privatization of police]. Bulletin of Public Opinion, 1(81), 58-71.

Gudkov, L., Dubin, B., \& Leonova, A. (2004). Militseiskoe nasilie i problema "politseiskogo gosudarstva" [Police violence and the problem of 'police state"]. Bulletin of Public Opinion, 4(72), 31-47.

Hinds, L., \& Murphy, K. (2007). Public Satisfaction with police: using procedural justice to improve police legitimacy. The Australian and New Zealand Journal of Criminology, 40(1), 27-42.

Ho, T., \& McKean, J. (2004). Confidence in the Police and Perception of Risk. Western Criminology Review, 5(2), 108-118.

Human Rights Watch. (1999). Confessions at Any Cost. Police Torture in Russia. New York, Washington DC, London, Brussels: Human Rights Watch.

ICVS. (1992). Database. Cross-tabulations. Retrieved 8.04.06, from https://easy.dans.knaw.nl/dms

ICVS. (1996). Database. Cross-tabulations. Retrieved 8.04.06, from https://easy.dans.knaw.nl/dms

IKSI. (1996). Monitoring IKSI 1996-IV [Institute of Complex Strategic Research]. Retrieved 2.8.10, from http://sophist.hse.ru

INDEM. (2001). Uluchshenie vzaimootnoshenii grazhdan i militsii [Improving the public-police relations]. Moscow: INDEM.

INDEM. (2004). Uchet mneniya grazhdan $v$ planirovanii $i$ otsenke deyatel'nosti militsii [Considering public opinion on evaluation of police work]. Moscow: Fund INDEM.

INDEM. (2007). Opredelenie faktorov vliyayuschikh na effektivnost' predostavleniya uslug po bezopasnosti ot prestupnykh posyagatel'stv [Determining the factors impacting the effectiveness of protection services from crimes]. Moscow: INDEM.

Ivanova, V. A., \& Shubkin, V. N. (2005). Massovaya trevozschnost' Rossiyan kak prepyatstvie $\mathrm{k}$ integratsii obschestva [Massive anxiety of Russians as the obstacle to the societal integration]. Social Research, 2, 22-28.

Jackson, J., Pooler, T., Hohl, K., Kuha, J., Bradford, B., \& Hough, M. (2011). European Social Survey.Trust in Justice. Available from www.europeansocialsurvey.org

Kakachia, K., \& O'Shea, L. (2012). Why does police reform appear to have been more successful in Georgia than in Kyrgyzstan or Russia? The Journal of Power Institutions in post-Soviet societies, 13.

Khabarov, R. (2011). Reforma politsii - otrabotanye praktiki v novoi aranzhirovke [Police reform - old practices in new form]. Bulletin of Fund of Public Verdict, 2(11), 23-24. 
NOT THE PUBLISHED VERSION; this is the author's final, peer-reviewed manuscript. The published version may be

accessed by following the link in the citation at the bottom of the page.

Lelekov , V. A., \& Tyamin, A. V. (2005). Zaschishennost' lichnosti ot prestupnyh posyagatelstv [Personal security from crime acts]. Social Research, 6, 107-108.

Levada. (2011). Problema korruptsii v Rossii [The problem of corruption in Russia] Retrieved from http://bd.fom.ru/pdf/d04pkvr11.pdf

Levada. (2013). Indeks doveriya politsii [Index of trust of police]. Retrieved 3.29.13, from www.levada.ru

Light, M. (2014). Police reforms in the Republic of Georgia: the convergence of domestic and foreign policy in an anti-corruption drive. Policing and Society, 24(3): 318-345

MacFadyen, D. (2008). Russian Television Today. London and New York: Routledge.

Makarova, M. N. (2011). Osobennosti vospriyatiya organov vnutrennokh delv obschestvennom mnenii regiona [Details of public opinion of police in the region]. Monitoring of Public Opinion, 1(101), 64-70.

Mazaev, Y. N. (2004). Rol' sredstv massovoi informatsii $v$ formirovanii obschestvennogo mneniya o militsii [The role of mass media in shaping the public opinion about police]. Social Research, 2, 106-115.

Murphy, K., Hinds, L., \& Fleming, J. (2008). Encouraging public cooperation and support for police. Policing \& Society, 18(2), 136-155.

Nagin, D. S. (1998). Criminal deterrence research at the outset of the 21st century. Crime and Justice: A Review of Research, 23, 1-42.

O'Connell, A. A. (2006). Logistic regression models for ordinal response variables. Thousand Oaks, CA: Sage.

Public Verdict Fund. (2008). Otnoshenie naselenia k reforme militsii [Public attitudes about police reform] Available from www.publicverdict.org

Public Verdict Fund. (2010). Reforma militisii: otsenki i ozhidaniya grazhdan [Police reform: public expectations and assessment] Available from www.publicverdict.org

Public Verdict Fund. (2012). Doklad rossiskih nepravitelstvenneykh organizatsii po sobludeniyu Rossiskoi Federatsii Konventsii protiv pytok 2006-2012 [The report of Russian NGOs on implementation of Convention against torture during 2006-2012] Available from http://publicverdict.ru

Robertson, A. (2004). Police Reform in Russia. In M. Caparini \& O. Marenin (Eds.), Transforming police in Central and Eastern Europe: process and progress (pp. 289-304). Munster, Germany: Lit Verlag

Reisig, M. D. (2007). Procedural Justice and Community Policing - What Shapes Resident's Willingness to Participate in Crime Prevention Programs. Policing: A Journal of Policy and Practice, 1, 356-369.

Reisig, M. D., Bratton, J., \& Gertz, M. G. (2007). The Construct validity and refinment of process-based policing measures. Criminal Justice and Behavior, 34(8), 1005-1028.

Police Practice and Research, Vol. 17, No. 3 (June 2016): pg. 229-248. DOI. This article is @ Taylor \& Francis (Routledge) and permission has been granted for this version to appear in e-Publications@Marquette. Taylor \& Francis (Routledge) does not grant permission for this article to be further copied/distributed or hosted elsewhere without the express permission from Taylor \& Francis (Routledge). 
NOT THE PUBLISHED VERSION; this is the author's final, peer-reviewed manuscript. The published version may be

accessed by following the link in the citation at the bottom of the page.

Reisig, M. D., \& Lloyd, C. (2009). Procedural Justice, Police Legitimacy, and Helping the Police to Fight Crime. Police Quarterly, 12(1), 42-62.

Reisig, M. D., Tankebe, J., \& Mesko, G. (2014). Compliance with the law in Slovenia: the role of procedural justice and police legitimacy. European Journal of Criminal Policy and Research, 20: 259-276

Reisig, M. D., Tankebe, J., \& Mesko, G. (2014). Procedural Justice, Police Legitimacy, and Public Cooperation with the Police among Young Slovene Adults. Journal of Criminal Justice and Security, 14(2), 147164.

Rimskyi, V. L. (2012). Rezultaty sotsiologicheskih issledovanii ispolneniya gosudratvom pravookhranitelnoi funktsii [Results of sociological surveys of law enforcement functions of the state] Available from http://www.indem.ru/proj/rpf/ReSoIsIspGoPF.pdf

Savel'ev, A. I. (2010). Obschestvennoe mnenie o deyatelnosti milisii v Omskoi oblasti [Public opinion on police in Omsk region]. Scientific bulletin of Omsk Academy of MVD, 1, 25-27.

Semukhina, O., \& Reynolds, K. M. (2013). Understanding the modern Russian police. Boca Raton: CRC Press, Taylor and Francis Group.

Sergevnin, V., \& Kovalyov, O. (2013). Policing in Russia. In G. Mesko (Ed.), Handbook on Policing in Central and Eastern Europe (pp. 191-215). New York: Springler Science and Business Media.

Shepeleva, O., \& Novikova, A. (2005). The main problems of the contemporary police Reforming law enforcement agencies: overcoming arbitrary work practices (pp. 40-56). Moscow: Demos Center.

Shubkin, V. N. (1997). Strahi v Rossii [Fears in Russia]. Sociological journal, 3, 62-78.

Skogan, W. G., \& Frydl, K. (2004). Fairness and effectiveness in policing: the evidence. Washington DC: Committee to Review Research on Police Policy and Practices. Committee on Law and Justice,Division of Behavioral and Social Sciences and Education, National Research Council, The National Academies Press.

Sunshine, J., \& Tyler, T. R. (2003). The Role of Procedural Justice and Legitimacy in Shaping Public Support for Policing. Law \& Society Review, 37(3), 513-547.

Tankebe, J. (2008). Police effectivness and police trustworthiness in Ghana. Criminology and Criminal Justice, 8(2), 185-202.

Tankebe, J. (2013). Viewing things differently: the dimensions of public perceptions of police legitimacy. Criminology, 51(1), 103-135.

Taylor, B. D. (2011). State Building in Putin's Russia. New York: Cambridge University Press.

Tyler, T. R. (2006). Why People Obey the Law. Princeton, NJ: Princeton University Press

Police Practice and Research, Vol. 17, No. 3 (June 2016): pg. 229-248. DOI. This article is (C) Taylor \& Francis (Routledge) and permission has been granted for this version to appear in e-Publications@Marquette. Taylor \& Francis (Routledge) does not grant permission for this article to be further copied/distributed or hosted elsewhere without the express permission from Taylor \& Francis (Routledge). 
Tyler, T. R. (2013). Why People Cooperate: The Role of Social Motivations. Princeton, NJ: Princeton University Press

Tyler, T. R., Braga, A., Fagan, J., Meares, T., Sampson, R., \& Winship, C. (2007). Legitimacy and Criminal Justice: Internatinal Perspectives. In T. R. Tyler (Ed.), Legitimacy and criminal justice (pp. 9-29). New York: Russel Sage Foundation.

Tyler, T. R., \& Huo, Y. (2002). Trust in the law. New York: Russell sage Foundation.

WCIOM. (1989). Blitz-WCIOM 1989-5. Retrieved 11.10.11, from http://wciom.ru/

WCIOM. (2012a). Politsiya i obschestvo: otnoshenie, doverie, vzaimodeistvie [Police and society: relations, trust and interaction]. Retrieved 3.30.13, from http://wciom.ru/index.php?id=515\&uid $=112346$

WCIOM. (2012b). Rabota politsii: obschestvennaya otsenka [The work of police: public opinion]. Retrieved 3.30.13, from http://wciom.ru/index.php?id $=515 \&$ uid $=113269$

WCIOM. (2012c). Uroven' bezopasnosti lichnosti i deyatelnosti organov vnutrennikh del [The levels of personal safety and the law enforcement activities]. Retrieved 3.30.13, from http://wciom.ru/index.php?id $=266 \&$ uid $=113276$

Zernova, M. (2012). Coping with the failure of the police in post-Soviet Russia: findings from one empirical study. Police Practice and Research, 13(6), 474-486.

Table 2. Comparison of Demographic Characteristics, and Crime Rates for the Russian Federation and Volgograd Region

\begin{tabular}{lllll}
\hline Criteria & \multicolumn{2}{c}{ Russian Federation } & & \\
\hline Age: & & & & $(5.25 \%)$ \\
$0-4$ & $7,955,703$ & $(5.61 \%)$ & 135,924 & $(4.57 \%)$ \\
$5-9$ & $6,880,863$ & $(4.85 \%)$ & 118,264 & $(4.46 \%)$ \\
$10-14$ & $6,564,046$ & $(4.63 \%)$ & 115,633 & $(6.01 \%)$ \\
$15-19$ & $8,495,662$ & $(5.99 \%)$ & 155,529 & $(8.39 \%)$ \\
$20-24$ & $12,256,143$ & $(8.64 \%)$ & 217,291 & $(8.41 \%)$ \\
$25-29$ & $12,257,349$ & $(8.64 \%)$ & 217,790 & $(7.41 \%)$ \\
$30-34$ & $10,798,991$ & $(7.61 \%)$ & 191,865 & $(6.94 \%)$ \\
$35-39$ & $10,068,892$ & $(7.10 \%)$ & 179,639 & $(6.42 \%)$ \\
$40-44$ & $9,193,316$ & $(6.48 \%)$ & 166,171 & $(7.78 \%)$ \\
$45-49$ & $11,247,260$ & $(7.93 \%)$ & 201,366 & $(7.66 \%)$ \\
$50-54$ & $11,260,733$ & $(7.93 \%)$ & 198,494 & $(7.01 \%)$ \\
$55-59$ & $9,747,960$ & $(6.87 \%)$ & 181,496 & $(5.07 \%)$ \\
$60-64$ & $6,896,925$ & $(4.86 \%)$ & 131,264 & $(3.63 \%)$ \\
$65-69$ & $4,479,576$ & $(3.16 \%)$ & 93,899 &
\end{tabular}

Police Practice and Research, Vol. 17, No. 3 (June 2016): pg. 229-248. DOI. This article is @ Taylor \& Francis (Routledge) and permission has been granted for this version to appear in e-Publications@Marquette. Taylor \& Francis (Routledge) does not grant permission for this article to be further copied/distributed or hosted elsewhere without the express permission from Taylor \& Francis (Routledge). 
NOT THE PUBLISHED VERSION; this is the author's final, peer-reviewed manuscript. The published version may be accessed by following the link in the citation at the bottom of the page.

\begin{tabular}{lllll}
$70-74$ & $6,169,297$ & $(4.35 \%)$ & 133,081 & $(5.14 \%)$ \\
$75-79$ & $3,616,578$ & $(2.55 \%)$ & 68,384 & $(2.64 \%)$ \\
$80-84$ & $2,763,382$ & $(1.95 \%)$ & 58,204 & $(2.25 \%)$ \\
85 plus & $1,179,354$ & $(0.83 \%)$ & 25,593 & $(0.99 \%)$ \\
Place of residence & & & & \\
Urban & $103,705,314$ & $(73 \%)$ & $1,954,995$ & $(75.5 \%)$ \\
$\begin{array}{l}\text { Rural } \\
\text { Gender }\end{array}$ & $38,209,195$ & $(27 \%)$ & 63,4892 & $(24.5 \%)$ \\
$\begin{array}{l}\text { Male } \\
\text { Female }\end{array}$ & $67,605,133$ & $(46.6 \%)$ & $1,255,594$ & $(46.5 \%)$ \\
Education & $77,561,598$ & $(53.4 \%)$ & $1,443,629$ & $(53.5 \%)$ \\
$\begin{array}{l}\text { Incomplete school or lower } \\
\text { High school }\end{array}$ & $27,915,580$ & $(23.1 \%)$ & 517,447 & $(22.9 \%)$ \\
$\begin{array}{l}\text { Special professional education } \\
\text { Incomplete college degree }\end{array}$ & $21,276,555$ & $(17.5 \%)$ & 424,269 & $(18.8 \%)$ \\
$\begin{array}{l}\text { College degree } \\
\text { Graduate college degree }\end{array}$ & $48,296,055$ & $(39.8 \%)$ & 923,011 & $(40.7 \%)$ \\
Crime rates: & $3,739,718$ & $(3.1 \%)$ & 59,181 & $(2.6 \%)$ \\
$\begin{array}{l}\text { Registered crimes (per 100,000 } \\
\text { population) } \\
\text { Change compare to the previous } \\
\text { year }\end{array}$ & $19,009,265$ & $(15.7 \%)$ & 333,628 & $(14.8 \%)$ \\
$\begin{array}{l}\text { Resolved crimes (per 100,000 } \\
\text { population) } \\
\text { Change compare to the previous } \\
\text { year }\end{array}$ & $-1,638,562$ & $(1,128)$ & 31,206 & $(1,156)$ \\
\hline
\end{tabular}

Sources:Age, gender and education data are retrieved from the latest all-Russian Census as of 01.01.2010. Information is available from the official web-site of the State Statistical Agency of Russia at www.gks.ru. Crime rate statistics for 2008 are retrieved from the official website of the Ministry of Interior Affairs of Russia at www.mvd.ru 
NOT THE PUBLISHED VERSION; this is the author's final, peer-reviewed manuscript. The published version may be accessed by following the link in the citation at the bottom of the page.

Table 1. Summary of empirical studies on Russian police

\begin{tabular}{|c|c|c|}
\hline \multirow{2}{*}{\multicolumn{3}{|c|}{ Criteria }} \\
\hline & & \\
\hline & Yes & No \\
\hline ICVS, 1992 (theft) & $31.7 \%$ & $68.3 \%$ \\
\hline $\begin{array}{l}\text { ICVS, } 1996 \\
\text { (embezzlement) }\end{array}$ & $4.6 \%$ & $95.4 \%$ \\
\hline Egoryshev, 1997 & $29 \%$ & $71 \%$ \\
\hline Makarova, 2011 & $44 \%$ & $54 \%$ \\
\hline \multicolumn{3}{|c|}{ Are you willing to assist police in criminal investigation? } \\
\hline & Yes & No \\
\hline Bezaev, 1999 & $24.5 \%$ & \\
\hline Public Verdict Fund, 2008 & $32 \%$ & \\
\hline WCIOM, 2012c & & $46 \%$ \\
\hline Levada, 2013 & $43 \%$ & \\
\hline \multicolumn{3}{|c|}{ Are you willing to contact police in a life-threatening situation? } \\
\hline & Yes & No \\
\hline INDEM, 2004 & & $29 \%$ \\
\hline Gudkov, 2004 & $67 \%$ & \\
\hline $\begin{array}{l}\text { Ermolaev, } 2007 \text { (police } \\
\text { officers) }\end{array}$ & $69 \%$ & \\
\hline Makarova, 2011 & & $24.8 \%$ \\
\hline \multicolumn{3}{|l|}{ Do you trust the police? } \\
\hline & Yes & No \\
\hline WCIOM,1989 & $18.6 \%$ & $26.9 \%$ \\
\hline IKSI, 1996 & $19.5 \%$ & $57.1 \%$ \\
\hline FOM,1997 & $19 \%$ & $55 \%$ \\
\hline Robertson, 2004 & $45 \%$ & $39 \%$ \\
\hline Levada, 2011 & $35 \%$ & $56 \%$ \\
\hline WCIOM, 2012a & $49 \%$ & \\
\hline Levada, 2013 & $48 \%$ & \\
\hline \multicolumn{3}{|c|}{ Do you fear the police officers? } \\
\hline & Yes & No \\
\hline Gudkov, 2004 & $46 \%$ & $54 \%$ \\
\hline Gryaznova, 2006 & $24 \%$ & \\
\hline Public Verdict, 2008 & $28 \%$ & \\
\hline FOM, 2012b & $37 \%$ & $56 \%$ \\
\hline
\end{tabular}

Police Practice and Research, Vol. 17, No. 3 (June 2016): pg. 229-248. DOI. This article is (C Taylor \& Francis (Routledge) and permission has been granted for this version to appear in e-Publications@Marquette. Taylor \& Francis (Routledge) does not grant permission for this article to be further copied/distributed or hosted elsewhere without the express permission from Taylor \& Francis (Routledge). 
NOT THE PUBLISHED VERSION; this is the author's final, peer-reviewed manuscript. The published version may be accessed by following the link in the citation at the bottom of the page.

Table 6. Logistic regression model for unwillingness to assist police during criminal investigation

\begin{tabular}{lrrrrr}
\hline Variables & \multicolumn{1}{c}{ B } & Std. Error & Wald & Exp(B) & Sig. \\
\hline Fear of police & .311 & .143 & 4.745 & 1.365 & $.029 *$ \\
Police avoidance & .544 & .114 & 22.613 & 1.724 & $.000^{*}$ \\
Protected from crime by police & -.007 & .148 & .002 & 1.007 & .965 \\
Victimization & .752 & .321 & 5.496 & .471 & $.019 *$ \\
Gender & .002 & .266 & .000 & 1.002 & .441 \\
Education & .163 & .114 & 2.063 & 1.117 & .154 \\
Occupation & -.113 & .112 & 1.026 & .893 & .311 \\
Age & -.160 & .092 & 3.003 & .852 & .082 \\
Monthly income & -.351 & .120 & 8.590 & .704 & $.003 *$ \\
Contact with police in the last & .214 & .291 & .535 & 1.237 & .464 \\
12 months & & & & & \\
Police trust & -.135 & .144 & .887 & .874 & $.034 *$ \\
\hline
\end{tabular}

*- significant for 5 percent level

Police Practice and Research, Vol. 17, No. 3 (June 2016): pg. 229-248. DOI. This article is (C Taylor \& Francis (Routledge) and permission has been granted for this version to appear in e-Publications@Marquette. Taylor \& Francis (Routledge) does not grant permission for this article to be further copied/distributed or hosted elsewhere without the express permission from Taylor \& Francis (Routledge). 
NOT THE PUBLISHED VERSION; this is the author's final, peer-reviewed manuscript. The published version may be accessed by following the link in the citation at the bottom of the page.

Table 3. Public-police cooperation, fear of police and demographics It can be dangerous to assist police during the criminal investigation When a police officer approaches someone they feel scared Strongly Disagree Neither Agree Strongly Total Never Seldom Sometimes Most of Always Total disagree

agree agree
the time

isagree

\begin{tabular}{|c|c|c|c|c|c|c|c|c|c|c|c|c|}
\hline \multicolumn{13}{|l|}{ Age: } \\
\hline $18-21$ & $\begin{array}{c}10 \\
(21.7 \%)\end{array}$ & $12(11.7 \%)$ & $\begin{array}{c}26 \\
(21.5 \%)\end{array}$ & $41(20.6 \%)$ & $\begin{array}{c}10 \\
(14.3 \%)\end{array}$ & $\begin{array}{c}99 \\
(18.4 \%)\end{array}$ & $\begin{array}{c}2 \\
(28.6 \%)\end{array}$ & $\begin{array}{c}5 \\
(16.7 \%)\end{array}$ & $18(17.5 \%)$ & $\begin{array}{c}26 \\
(18.7 \%)\end{array}$ & $\begin{array}{c}48 \\
(18.4 \%)\end{array}$ & $99(18.3 \%)$ \\
\hline $22-30$ & $\begin{array}{c}9 \\
(19.6 \%)\end{array}$ & $10(9.7 \%)$ & $\begin{array}{c}22 \\
(18.2 \%)\end{array}$ & $\begin{array}{c}43 \\
(21.6 \%)\end{array}$ & $\begin{array}{c}18 \\
(25.7 \%)\end{array}$ & $\begin{array}{c}102 \\
(18.9 \%)\end{array}$ & $(14.3 \%)$ & $\begin{array}{c}8 \\
(26.7 \%)\end{array}$ & $25(24.3 \%)$ & $\begin{array}{c}22 \\
(15.8 \%)\end{array}$ & $\begin{array}{c}46 \\
(17.6 \%)\end{array}$ & $\begin{array}{c}102 \\
(18.9 \%)\end{array}$ \\
\hline $31-40$ & $\begin{array}{c}5 \\
(10.9 \%)\end{array}$ & $23(22.3 \%)$ & $\begin{array}{c}23 \\
(19 \%)\end{array}$ & $\begin{array}{c}33 \\
(16.6 \%)\end{array}$ & $8(11.4 \%)$ & $\begin{array}{c}92 \\
(17.1 \%)\end{array}$ & $\begin{array}{c}2 \\
(28.6 \%)\end{array}$ & $\begin{array}{c}7 \\
(23.3 \%)\end{array}$ & $15(14.6 \%)$ & $\begin{array}{c}31 \\
(22.3 \%)\end{array}$ & $37(14.2 \%)$ & $92(17 \%)$ \\
\hline $41-50$ & $\begin{array}{c}12 \\
(26.1 \%)\end{array}$ & $27(26.2 \%)$ & $\begin{array}{c}25 \\
(20.7 \%)\end{array}$ & $\begin{array}{c}33 \\
(16.6 \%)\end{array}$ & $6(8.6 \%)$ & $\begin{array}{c}103 \\
(19.1 \%)\end{array}$ & $\begin{array}{c}2 \\
(28.6 \%)\end{array}$ & $6(20 \%)$ & $21(20.4 \%)$ & $\begin{array}{c}25 \\
(18 \%)\end{array}$ & $\begin{array}{c}49 \\
(18.8 \%)\end{array}$ & $\begin{array}{c}103 \\
(19.1 \%)\end{array}$ \\
\hline $51-60$ & $\begin{array}{c}5 \\
(10.9 \%)\end{array}$ & $14(13.6 \%)$ & $\begin{array}{c}11 \\
(9.1 \%)\end{array}$ & $\begin{array}{c}27 \\
(13.6 \%)\end{array}$ & $\begin{array}{c}11 \\
(15.7 \%)\end{array}$ & $68(12.6 \%)$ & $0(0 \%)$ & $3(10 \%)$ & $14(13.6 \%)$ & $\begin{array}{c}18 \\
(12.9 \%)\end{array}$ & $\begin{array}{c}33 \\
(12.6 \%)\end{array}$ & $68(12.6 \%)$ \\
\hline 60 plus & $\begin{array}{c}5 \\
(10.9 \%)\end{array}$ & $17(16.5 \%)$ & $\begin{array}{c}14 \\
(11.6 \%)\end{array}$ & $\begin{array}{c}22 \\
(11.1 \%)\end{array}$ & $17(24.3 \%)$ & $\begin{array}{c}75 \\
(13.9 \%)\end{array}$ & $0(0 \%)$ & $\begin{array}{c}1 \\
(3.3 \%)\end{array}$ & $10(9.7 \%)$ & $\begin{array}{c}17 \\
(12.2 \%)\end{array}$ & $\begin{array}{c}48 \\
(18.4 \%)\end{array}$ & $76(14.1 \%)$ \\
\hline \multicolumn{13}{|l|}{ Gender } \\
\hline Male & $\begin{array}{c}27 \\
(58.7 \%)\end{array}$ & $51(49.5 \%)$ & $\begin{array}{c}57 \\
(47.1 \%)\end{array}$ & $\begin{array}{c}97 \\
(48.7 \%)\end{array}$ & $35(50 \%)$ & $\begin{array}{c}267 \\
(49.5 \%)\end{array}$ & $\begin{array}{c}6 \\
(85.7 \%)\end{array}$ & $\begin{array}{c}11 \\
(36.7 \%)\end{array}$ & $48(46.6 \%)$ & $\begin{array}{c}70 \\
(50.4 \%)\end{array}$ & $\begin{array}{c}132 \\
(50.6 \%)\end{array}$ & $267(49.4 \%)$ \\
\hline Female & $\begin{array}{c}19 \\
(41.3 \%)\end{array}$ & $52(50.5 \%)$ & $\begin{array}{c}64 \\
(52.9 \%)\end{array}$ & $\begin{array}{c}102 \\
(51.3 \%)\end{array}$ & $35(50 \%)$ & $\begin{array}{c}272 \\
(50.5 \%)\end{array}$ & $\begin{array}{c}1 \\
(14.3 \%)\end{array}$ & $\begin{array}{c}19 \\
(63.3 \%)\end{array}$ & $55(53.4 \%)$ & $\begin{array}{c}69 \\
(49.6 \%)\end{array}$ & $\begin{array}{c}129 \\
(49.4 \%)\end{array}$ & $\begin{array}{c}273 \\
(50.6 \%)\end{array}$ \\
\hline $\begin{array}{l}\text { Occupation: } \\
\text { Small } \\
\text { business } \\
\text { owner }\end{array}$ & $\begin{array}{c}4 \\
(8.7 \%)\end{array}$ & $9(8.7 \%)$ & $\begin{array}{c}13 \\
(10.7 \%)\end{array}$ & $\begin{array}{c}22 \\
(11.1 \%)\end{array}$ & $7(10 \%)$ & $\begin{array}{c}55 \\
(10.2 \%)\end{array}$ & $0(0 \%)$ & $\begin{array}{c}4 \\
(13.3 \%)\end{array}$ & $7(6.8 \%)$ & $\begin{array}{c}21 \\
(15.1 \%)\end{array}$ & $23(8.8 \%)$ & 55 \\
\hline $\begin{array}{l}\text { Industry } \\
\text { employee }\end{array}$ & $\begin{array}{c}16 \\
(34.8 \%)\end{array}$ & $26(25.2 \%)$ & $\begin{array}{c}20 \\
(16.5 \%)\end{array}$ & $\begin{array}{c}40 \\
(20.1 \%)\end{array}$ & $9(12.9 \%)$ & $\begin{array}{c}111 \\
(20.6 \%)\end{array}$ & $\begin{array}{c}2 \\
(28.6 \%)\end{array}$ & $\begin{array}{c}7 \\
(23.3 \%)\end{array}$ & $19(18.4 \%)$ & $\begin{array}{c}29 \\
(20.9 \%)\end{array}$ & $\begin{array}{c}54 \\
(20.7 \%)\end{array}$ & $\begin{array}{c}111 \\
(20.6 \%)\end{array}$ \\
\hline $\begin{array}{l}\text { Office } \\
\text { employee }\end{array}$ & $\begin{array}{c}9 \\
(19.6 \%)\end{array}$ & $28(27.2 \%)$ & $\begin{array}{c}36 \\
(29.8 \%)\end{array}$ & $\begin{array}{c}47 \\
(23.6 \%)\end{array}$ & $\begin{array}{c}10 \\
(14.3 \%)\end{array}$ & $\begin{array}{c}130 \\
(24.1 \%)\end{array}$ & $\begin{array}{c}3 \\
(42.9 \%)\end{array}$ & $\begin{array}{c}6 \\
(20.6 \%)\end{array}$ & $37(35.9 \%)$ & $\begin{array}{c}34 \\
(24.5 \%)\end{array}$ & $\begin{array}{c}50 \\
(19.2 \%)\end{array}$ & $\begin{array}{c}130 \\
(24.1 \%)\end{array}$ \\
\hline Student & $\begin{array}{c}8 \\
(17.4 \%)\end{array}$ & $10(9.7 \%)$ & $\begin{array}{c}23 \\
(19 \%)\end{array}$ & $\begin{array}{c}46 \\
(23.1 \%)\end{array}$ & $\begin{array}{c}16 \\
(21.4 \%)\end{array}$ & $\begin{array}{c}102 \\
(18.9 \%)\end{array}$ & $\begin{array}{c}2 \\
(28.6 \%)\end{array}$ & $\begin{array}{c}4 \\
(13.3 \%)\end{array}$ & $22(21.4 \%)$ & $\begin{array}{c}25 \\
(18 \%)\end{array}$ & $49(18 \%)$ & $\begin{array}{c}102 \\
(18.9 \%)\end{array}$ \\
\hline Unemployed & $\begin{array}{c}3 \\
(6.5 \%)\end{array}$ & $3(2.9 \%)$ & $\begin{array}{c}12 \\
(9.9 \%)\end{array}$ & $10(5 \%)$ & $2(2.9 \%)$ & $30(5.6 \%)$ & $0(0 \%)$ & $6(20 \%)$ & $4(3.9 \%)$ & $\begin{array}{c}5 \\
(3.6 \%)\end{array}$ & $15(5.7 \%)$ & $30(5.6 \%)$ \\
\hline Retired & $6(13 \%)$ & $27(26.2 \%)$ & $\begin{array}{c}17 \\
(14 \%)\end{array}$ & $\begin{array}{c}34 \\
(17.1 \%)\end{array}$ & $\begin{array}{c}27 \\
(38.6 \%)\end{array}$ & $\begin{array}{c}111 \\
(20.6 \%)\end{array}$ & $0(0 \%)$ & $3(10 \%)$ & $14(13.6 \%)$ & $\begin{array}{c}25 \\
(18 \%)\end{array}$ & $\begin{array}{c}70 \\
(28.6 \%)\end{array}$ & $\begin{array}{c}112 \\
(20.7 \%)\end{array}$ \\
\hline \multicolumn{13}{|l|}{ Income: } \\
\hline Under $4 \mathrm{~K}$ & $\begin{array}{c}5 \\
(12.5 \%)\end{array}$ & $13(14.6 \%)$ & $\begin{array}{c}18 \\
(17.1 \%)\end{array}$ & $\begin{array}{c}40 \\
(22.1 \%)\end{array}$ & $\begin{array}{c}16 \\
(23.5 \%)\end{array}$ & $92(19 \%)$ & $1(14.3 \%)$ & $\begin{array}{c}5 \\
(19.2 \%)\end{array}$ & $18(19.1 \%)$ & $\begin{array}{c}21 \\
(17.2 \%)\end{array}$ & $47(20 \%)$ & $92(19 \%)$ \\
\hline $4 K-7 K$ & $8(20 \%)$ & $19(21.3 \%)$ & $\begin{array}{c}21 \\
(20 \%)\end{array}$ & $\begin{array}{c}53 \\
(29.3 \%)\end{array}$ & $\begin{array}{c}24 \\
(35.3 \%)\end{array}$ & $\begin{array}{c}125 \\
(25.9 \%)\end{array}$ & $\begin{array}{c}2 \\
(28.6 \%)\end{array}$ & $\begin{array}{c}4 \\
(15.4 \%)\end{array}$ & $24(25.5 \%)$ & $\begin{array}{c}31 \\
(25.4 \%)\end{array}$ & $\begin{array}{c}65 \\
(27.7 \%)\end{array}$ & $126(26 \%)$ \\
\hline $7 \mathrm{~K}-11 \mathrm{~K}$ & $\begin{array}{c}13 \\
(32.5 \%)\end{array}$ & $23(25.8 \%)$ & $\begin{array}{c}25 \\
(23.8 \%)\end{array}$ & $\begin{array}{c}28 \\
(15.5 \%)\end{array}$ & $\begin{array}{c}14 \\
(20.6 \%)\end{array}$ & $\begin{array}{c}103 \\
(21.3 \%)\end{array}$ & $0(0 \%)$ & $\begin{array}{c}7 \\
(26.9 \%)\end{array}$ & $23(24.5 \%)$ & $\begin{array}{c}30 \\
(24.6 \%)\end{array}$ & $\begin{array}{c}43 \\
(18.3 \%)\end{array}$ & $30(21.3 \%)$ \\
\hline $11 \mathrm{~K}-18 \mathrm{~K}$ & $8(20 \%)$ & 15 (16.9\%) & $\begin{array}{c}27 \\
(25.7 \%)\end{array}$ & $\begin{array}{c}35 \\
(19.3 \%)\end{array}$ & $8(11.8 \%)$ & $\begin{array}{c}93 \\
(19.3 \%)\end{array}$ & $\begin{array}{c}3 \\
(42.9 \%)\end{array}$ & $\begin{array}{c}4 \\
(15.4 \%)\end{array}$ & $21(22.3 \%)$ & $\begin{array}{c}25 \\
(20.5 \%)\end{array}$ & $40(17 \%)$ & $93(19.2 \%)$ \\
\hline $18 \mathrm{~K}-25 \mathrm{~K}$ & $\begin{array}{c}3 \\
(7.5 \%)\end{array}$ & $13(14.6 \%)$ & $\begin{array}{c}8 \\
(7.6 \%)\end{array}$ & $15(8.3 \%)$ & $5(7.4 \%)$ & $44(9.1 \%)$ & $\begin{array}{c}1 \\
(14.3 \%)\end{array}$ & $\begin{array}{c}5 \\
(19.2 \%)\end{array}$ & $5(5.3 \%)$ & $\begin{array}{c}10 \\
(8.2 \%)\end{array}$ & $23(9.8 \%)$ & $44(9.1 \%)$ \\
\hline $25 \mathrm{~K}$ and up & $\begin{array}{c}3 \\
(7.5 \%)\end{array}$ & $6(6.7 \%)$ & $\begin{array}{c}6 \\
(5.7 \%)\end{array}$ & $10(5.5 \%)$ & $1(1.5 \%)$ & $26(5.4 \%)$ & $0(0 \%)$ & $\begin{array}{c}1 \\
(3.8 \%)\end{array}$ & $3(3.2 \%)$ & $\begin{array}{l}5 \\
(4.1 \%)\end{array}$ & $17(7.2 \%)$ & $26(5.4 \%)$ \\
\hline $\begin{array}{l}\text { Total/\% of } \\
\text { total }\end{array}$ & $\begin{array}{c}46 \\
(8.5 \%) \\
\end{array}$ & $103(19.1 \%)$ & $\begin{array}{c}121 \\
(22.4 \%) \\
\end{array}$ & $\begin{array}{c}199 \\
(36.9 \%) \\
\end{array}$ & $70(13 \%)$ & $\begin{array}{c}539 \\
(100 \%) \\
\end{array}$ & $7(1.3 \%)$ & $\begin{array}{c}30 \\
(5.6 \%) \\
\end{array}$ & $103(19.1 \%)$ & $\begin{array}{c}139 \\
(25.7 \%) \\
\end{array}$ & $\begin{array}{c}261 \\
(48.3 \%) \\
\end{array}$ & $540(100 \%)$ \\
\hline
\end{tabular}

Police Practice and Research, Vol. 17, No. 3 (June 2016): pg. 229-248. DOI. This article is @ Taylor \& Francis (Routledge) and permission has been granted for this version to appear in e-Publications@Marquette. Taylor \& Francis (Routledge) does not grant permission for this article to be further copied/distributed or hosted elsewhere without the express permission from Taylor \& Francis (Routledge). 
NOT THE PUBLISHED VERSION; this is the author's final, peer-reviewed manuscript. The published version may be accessed by following the link in the citation at the bottom of the page.

Table 4. Police avoidance, police effectiveness, and demographics

\begin{tabular}{|c|c|c|c|c|c|c|c|c|c|c|c|c|}
\hline & \multicolumn{6}{|c|}{ Even if you don't break the rules it is better to avoid the police } & \multicolumn{6}{|c|}{ I feel protected from crime by police in my city/region } \\
\hline & $\begin{array}{l}\text { Strongly } \\
\text { disagree }\end{array}$ & Disagree & $\begin{array}{c}\text { Neither } \\
\text { agree nor } \\
\text { disagree }\end{array}$ & Agree & $\begin{array}{l}\text { Strongly } \\
\text { agree }\end{array}$ & Total & $\begin{array}{c}\text { Completely } \\
\text { unprotected }\end{array}$ & Unprotected & $\begin{array}{l}\text { Neither/ nor } \\
\text { (un)protected }\end{array}$ & Protected & $\begin{array}{c}\text { Completely } \\
\text { protected }\end{array}$ & Total \\
\hline \multicolumn{13}{|l|}{ Age: } \\
\hline $18-21$ & $\begin{array}{c}10 \\
(21.3 \%)\end{array}$ & $7(12.7 \%)$ & $22(19.5 \%)$ & $36(20.5 \%)$ & $24(16.1 \%)$ & $99(18.3 \%)$ & $2(7.1 \%)$ & $11(17.7 \%)$ & $35(16.7 \%)$ & $37(21.9 \%)$ & $14(19.4 \%)$ & $99(18.3 \%)$ \\
\hline $22-30$ & $\begin{array}{c}14 \\
(29.8 \%)\end{array}$ & $13(23.6 \%)$ & $14(12.4 \%)$ & $32(18.2 \%)$ & $29(19.5 \%)$ & $102(18.9 \%)$ & $2(7.1 \%)$ & $9(14.5 \%)$ & $46(22 \%)$ & $33(19.5 \%)$ & $12(16.7 \%)$ & $102(18.9 \%)$ \\
\hline $31-40$ & $6(12.8 \%)$ & $8(14.5 \%)$ & $21(18.6 \%)$ & $39(22.2 \%)$ & $18(12.1 \%)$ & $92(17 \%)$ & $2(7.1 \%)$ & $12(19.4 \%)$ & $33(15.8 \%)$ & $31(18.3 \%)$ & $14(19.4 \%)$ & $92(17 \%)$ \\
\hline $41-50$ & $8(17 \%)$ & $13(23.6 \%)$ & $22(19.5 \%)$ & $31(17.6 \%)$ & $29(19.5 \%)$ & $103(19.1 \%)$ & $5(17.9 \%)$ & $6(9.7 \%)$ & $45(21.5 \%)$ & $34(20.1 \%)$ & $13(18.1 \%)$ & $103(19.1 \%)$ \\
\hline $51-60$ & $1(2.1 \%)$ & $7(12.7 \%)$ & $19(16.8 \%)$ & $17(9.7 \%)$ & $24(16.1 \%)$ & $68(12.6 \%)$ & $7(25 \%)$ & $14(22.6 \%)$ & $22(10.5 \%)$ & $18(10.7 \%)$ & $7(9.7 \%)$ & $68(12.6 \%)$ \\
\hline 60 plus & $8(17 \%)$ & $7(12.7 \%)$ & $15(13.3 \%)$ & $21(11.9 \%)$ & $25(16.8 \%)$ & $76(14.1 \%)$ & $10(35.7 \%)$ & $10(16.1 \%)$ & $28(13.4 \%)$ & $16(9.5 \%)$ & $12(16.7 \%)$ & $76(14.1 \%)$ \\
\hline \multicolumn{13}{|l|}{ Gender } \\
\hline Male & $\begin{array}{c}27 \\
(57.4 \%)\end{array}$ & $28(50.9 \%)$ & $69(61.1 \%)$ & $72(40.9 \%)$ & $71(47.7 \%)$ & $\begin{array}{c}267 \\
(49.4 \%)\end{array}$ & $12(42.9 \%)$ & $26(41.9 \%)$ & $110(52.6 \%)$ & $81(47.9 \%)$ & $38(52.8 \%)$ & $267(49.4 \%)$ \\
\hline Female & $\begin{array}{c}20 \\
(42.6 \%)\end{array}$ & $\begin{array}{c}27 \\
(49.1 \%)\end{array}$ & $44(38.9 \%)$ & $\begin{array}{c}104 \\
(59.1 \%)\end{array}$ & $78(52.3 \%)$ & $\begin{array}{c}283 \\
(50.6 \%)\end{array}$ & $16(57.1 \%)$ & $36(58.1 \%)$ & $99(47.4 \%)$ & $88(52.1 \%)$ & $34(47.2 \%)$ & $273(50.6 \%)$ \\
\hline \multicolumn{13}{|l|}{ Occupation: } \\
\hline $\begin{array}{l}\text { Small } \\
\text { business } \\
\text { owner }\end{array}$ & $1(2.1 \%)$ & $7(12.7 \%)$ & $6(5.3 \%)$ & $25(14.2 \%)$ & $16(10.7 \%)$ & $55(10.2 \%)$ & $1(3.6 \%)$ & $4(6.5 \%)$ & $22(10.5 \%)$ & $17(10.1 \%)$ & $11(15.3 \%)$ & $55(10.2 \%)$ \\
\hline $\begin{array}{l}\text { Industry } \\
\text { employee }\end{array}$ & $12(25.5 \%)$ & $14(25.5 \%)$ & $25(21.1 \%)$ & $32(18.2 \%)$ & $28(18.8 \%)$ & $111(20.6 \%)$ & $2(7.1 \%)$ & $9(14.5 \%)$ & $51(24.4 \%)$ & $37(21.9 \%)$ & $12(16.7 \%)$ & $111(20.6 \%)$ \\
\hline $\begin{array}{l}\text { Office } \\
\text { employee }\end{array}$ & $9(19.1 \%)$ & $13(23.6 \%)$ & $31(27.4 \%)$ & $46(26.1 \%)$ & $31(20.8 \%)$ & $130(24.1 \%)$ & $5(17.9 \%)$ & $14(22.6 \%)$ & $52(24.9 \%)$ & $42(24.9 \%)$ & $17(23.6 \%)$ & $130(24.1 \%)$ \\
\hline Student & $10(21.3 \%)$ & $7(12.7 \%)$ & $20(17.7 \%)$ & $35(19.9 \%)$ & $30(20.1 \%)$ & $102(18.9 \%)$ & $2(7.1 \%)$ & $14(22.6 \%)$ & $30(14.4 \%)$ & $40(23.7 \%)$ & $16(22.2 \%)$ & $102(18.9 \%)$ \\
\hline Unemployed & $6(12.8 \%)$ & $6(10.9 \%)$ & $7(6.2 \%)$ & $6(3.4 \%)$ & $5(3.4 \%)$ & $30(5.2 \%)$ & $2(7.1 \%)$ & $1(1.6 \%)$ & $13(6.2 \%)$ & $11(6.2 \%)$ & $3(4.2 \%)$ & $30(5.6 \%)$ \\
\hline Retired & $9(19.1 \%)$ & $8(14.5 \%)$ & $24(21.2 \%)$ & $32(18.2 \%)$ & $39(26.2 \%)$ & $112(20.7 \%)$ & $16(57.1 \%)$ & $20(32.3 \%)$ & $41(19.6 \%)$ & $22(13 \%)$ & $13(18.1 \%)$ & $112(20.7 \%)$ \\
\hline \multicolumn{13}{|l|}{ Income: } \\
\hline Under 4K & $9(22.5 \%)$ & $8(16.3 \%)$ & $22(22.2 \%)$ & $32(20.3 \%)$ & $21(15.2 \%)$ & $92(19 \%)$ & $6(22.2 \%)$ & $12(20.3 \%)$ & $35(18.6 \%)$ & $27(18.4 \%)$ & $12(19 \%)$ & $92(19 \%)$ \\
\hline $4 K-7 K$ & $12(30 \%)$ & $8(16.3 \%)$ & $25(25.3 \%)$ & $35(22.2 \%)$ & $46(33.3 \%)$ & $126(26 \%)$ & $12(44.4 \%)$ & $18(30.5 \%)$ & $43(22.9 \%)$ & $38(25.9 \%)$ & $15(23.8 \%)$ & $126(26 \%)$ \\
\hline $7 \mathrm{~K}-11 \mathrm{~K}$ & $6(15 \%)$ & $13(26.5 \%)$ & $20(20.2 \%)$ & $40(25.3 \%)$ & $24(17.4 \%)$ & $103(21.3 \%)$ & $5(18.5 \%)$ & $9(15.3 \%)$ & $38(20.2 \%)$ & $39(26.5 \%)$ & $12(19 \%)$ & $103(21.3 \%)$ \\
\hline $11 \mathrm{~K}-18 \mathrm{~K}$ & $9(22.5 \%)$ & $15(30.6 \%)$ & $15(15.2 \%)$ & $32(20.3 \%)$ & $22(15.9 \%)$ & $93(19.2 \%)$ & $3(11.1 \%)$ & $16(27.1 \%)$ & $36(19.1 \%)$ & $27(18.4 \%)$ & $11(17.5 \%)$ & $93(19.2 \%)$ \\
\hline $18 \mathrm{~K}-25 \mathrm{~K}$ & $3(7.5 \%)$ & $4(8.2 \%)$ & $11(11.1 \%)$ & $14(8.9 \%)$ & $12(8.7 \%)$ & $44(9.1 \%)$ & $0(0 \%)$ & $2(3.4 \%)$ & $23(12.2 \%)$ & $11(7.5 \%)$ & $8(12.7 \%)$ & $44(9.1 \%)$ \\
\hline $25 \mathrm{~K}$ and up & $1(2.5 \%)$ & $1(2 \%)$ & $6(6.1 \%)$ & $5(3.2 \%)$ & $13(9.4 \%)$ & $26(5.4 \%)$ & $1(3.7 \%)$ & $2(3.4 \%)$ & $13(6.9 \%)$ & $5(3.4 \%)$ & $5(7.9 \%)$ & $26(5.4 \%)$ \\
\hline $\begin{array}{l}\text { Total/\% of } \\
\text { total }\end{array}$ & $47(8.7 \%)$ & $55(10.2 \%)$ & $113(20.9 \%)$ & $176(32.6 \%)$ & $149(27.6 \%)$ & $540(100 \%)$ & $28(5.2 \%)$ & $62(11.5 \%)$ & $209(38.7 \%)$ & $169(31.3 \%)$ & $72(13.3 \%)$ & $540(100 \%)$ \\
\hline
\end{tabular}

Police Practice and Research, Vol. 17, No. 3 (June 2016): pg. 229-248. DOI. This article is @ Taylor \& Francis (Routledge) and permission has been granted for this version to appear in e-Publications@Marquette. Taylor \& Francis (Routledge) does not grant permission for this article to be further copied/distributed or hosted elsewhere without the express permission from Taylor \& Francis (Routledge). 
NOT THE PUBLISHED VERSION; this is the author's final, peer-reviewed manuscript. The published version may be accessed by following the link in the citation at the bottom of the page.

Table 5. Trust of police, police contact, victimization and demographics

\begin{tabular}{|c|c|c|c|c|c|c|c|c|c|c|c|c|}
\hline & \multicolumn{6}{|c|}{ How much do you trust the police } & \multicolumn{3}{|c|}{$\begin{array}{l}\text { Contact with police in the last } 12 \\
\text { months }\end{array}$} & \multicolumn{3}{|c|}{ Victimization in the last 12 months } \\
\hline & $\begin{array}{c}\text { Completely } \\
\text { distrust }\end{array}$ & Distrust & $\begin{array}{l}\text { Neither } \\
\text { trust nor } \\
\text { distrust }\end{array}$ & Trust & $\begin{array}{c}\text { Completely } \\
\text { trust }\end{array}$ & Total & Yes & No & Total & Yes & No & Total \\
\hline \multicolumn{13}{|l|}{ Age: } \\
\hline $18-21$ & $4(11.4 \%)$ & $18(23.4 \%)$ & $33(18.8 \%)$ & $35(17.4 \%)$ & $9(17.6 \%)$ & $99(18.3 \%)$ & $36(18 \%)$ & $54(18.2 \%)$ & $90(18.1 \%)$ & $24(19.8 \%)$ & $72(18.8 \%)$ & $96(19 \%)$ \\
\hline $22-30$ & $4(11.4 \%)$ & $14(18.2 \%)$ & $36(20.5 \%)$ & $37(18.4 \%)$ & $11(21.6 \%)$ & $102(18.9 \%)$ & $47(23.5 \%)$ & $52(17.6 \%)$ & $99(20 \%)$ & $25(20.7 \%)$ & $73(19 \%)$ & $98(19.4 \%)$ \\
\hline $31-40$ & $3(8.6 \%)$ & $10(13 \%)$ & $32(18.2 \%)$ & $38(18.9 \%)$ & $9(17.6 \%)$ & $92(17 \%)$ & $39(19.5 \%)$ & $47(15.9 \%)$ & $86(17.3 \%)$ & $20(16.5 \%)$ & $65(16.9 \%)$ & $85(16.8 \%)$ \\
\hline $41-50$ & $2(5.7 \%)$ & $8(10.4 \%)$ & $34(19.3 \%)$ & $51(25.4 \%)$ & $8(15.7 \%)$ & $103(19.1 \%)$ & $46(23 \%)$ & $44(14.9 \%)$ & $90(18.1 \%)$ & $26(21.5 \%)$ & $68(17.7 \%)$ & $94(18.6 \%)$ \\
\hline $51-60$ & $9(25.7 \%)$ & $10(13 \%)$ & $22(12.5 \%)$ & $20(10 \%)$ & $7(13.7 \%)$ & $68(12.6 \%)$ & $18(9 \%)$ & $44(14.9 \%)$ & $62(12.5 \%)$ & $13(10.7 \%)$ & $51(13.3 \%)$ & $64(12.7 \%)$ \\
\hline 60 plus & $13(37.1 \%)$ & $17(22.1 \%)$ & $19(10.8 \%)$ & $20(10 \%)$ & $7(13.7 \%)$ & $76(14.1 \%)$ & $14(7 \%)$ & $55(18.6 \%)$ & $69(13.9 \%)$ & $13(10.7 \%)$ & $55(14.3 \%)$ & $68(13.5 \%)$ \\
\hline \multicolumn{13}{|l|}{ Gender } \\
\hline Male & $12(34.3 \%)$ & $31(40.3 \%)$ & $84(47.7 \%)$ & $102(50.7 \%)$ & $38(74.5 \%)$ & $267(49.4 \%)$ & $94(47 \%)$ & $149(50.3 \%)$ & $243(49 \%)$ & $61(52.1 \%)$ & $183(47.7 \%)$ & $246(48.7 \%)$ \\
\hline Female & $23(65.7 \%)$ & $46(59.7 \%)$ & $92(52.3 \%)$ & $99(49.3 \%)$ & $13(25.5 \%)$ & $273(50.6 \%)$ & $106(53 \%)$ & $147(49.7 \%)$ & $253(51 \%)$ & $58(47.9 \%)$ & $201(52.3 \%)$ & $259(51.3 \%)$ \\
\hline \multicolumn{13}{|l|}{ Occupation: } \\
\hline $\begin{array}{l}\text { Small } \\
\text { business } \\
\text { owner }\end{array}$ & $1(2.9 \%)$ & $8(10.4 \%)$ & $17(9.7 \%)$ & $26(12.9 \%)$ & $3(5.9 \%)$ & $55(10.2 \%)$ & $23(11.5 \%)$ & $26(8.8 \%)$ & $49(9.9 \%)$ & $18(14.9 \%)$ & $32(8.3 \%)$ & $50(9.9 \%)$ \\
\hline $\begin{array}{l}\text { Industry } \\
\text { employee }\end{array}$ & $6(17.1 \%)$ & $11(14.3 \%)$ & $36(20.5 \%)$ & $45(22.4 \%)$ & $13(25.5 \%)$ & $111(20.6 \%)$ & $38(19 \%)$ & $62(20.9 \%)$ & $100(20.2 \%)$ & $23(19 \%)$ & $85(21.4 \%)$ & $108(20.8 \%)$ \\
\hline $\begin{array}{l}\text { Office } \\
\text { employee }\end{array}$ & $3(8.6 \%)$ & $13(16.9 \%)$ & $49(27.8 \%)$ & $51(25.4 \%)$ & $14(27.5 \%)$ & $130(24.1 \%)$ & $66(33 \%)$ & $55(18.6 \%)$ & $121(24.4 \%)$ & $29(24 \%)$ & $92(24 \%)$ & $121(24 \%)$ \\
\hline Student & $4(11.4 \%)$ & $18(23.4 \%)$ & $35(19.9 \%)$ & $36(17.9 \%)$ & $9(17.6 \%)$ & $102(18.9 \%)$ & $36(18 \%)$ & $60(20.3 \%)$ & $96(19.4 \%)$ & $21(17.4 \%)$ & $77(20.1 \%)$ & $98(19.4 \%)$ \\
\hline Unemployed & $2(5.7 \%)$ & $6(7.8 \%)$ & $7(4 \%)$ & $13(6.5 \%)$ & $2(3.9 \%)$ & $30(5.6 \%)$ & $14(7 \%)$ & $13(4.4 \%)$ & $27(5.4 \%)$ & $11(9.1 \%)$ & $18(4.7 \%)$ & $29(5.7 \%)$ \\
\hline Retired & $19(54.3 \%)$ & $21(27.3 \%)$ & $32(18.2 \%)$ & $30(14.9 \%)$ & $10(19.6 \%)$ & $112(20.7 \%)$ & $23(11.5 \%)$ & $80(27 \%)$ & $103(20.8 \%)$ & ) $19(15.7 \%)$ & $83(21.6 \%)$ & $102(20.2 \%)$ \\
\hline \multicolumn{13}{|l|}{ Income: } \\
\hline Under 4K & $7(21.9 \%)$ & $22(30.1 \%)$ & $33(21.4 \%)$ & $26(14.6 \%)$ & $4(8.5 \%)$ & $92(19 \%)$ & $27(15 \%)$ & $59(22.3 \%)$ & $86(19.4 \%)$ & $19(17.1 \%)$ & $67(19.6 \%)$ & $86(19 \%)$ \\
\hline $4 K-7 K$ & $11(34.4 \%)$ & $22(30.1 \%)$ & $34(22.1 \%)$ & $45(25.3 \%)$ & $14(29.8 \%)$ & $126(26 \%)$ & $39(21.7 \%)$ & $76(28.8 \%)$ & $115(25.9 \%)$ & ) $26(23.4 \%)$ & $91(26.7 \%)$ & $117(25.9 \%)$ \\
\hline $7 \mathrm{~K}-11 \mathrm{~K}$ & $5(15.6 \%)$ & $10(13.7 \%)$ & $35(22.7 \%)$ & $44(24.7 \%)$ & $9(19.1 \%)$ & $103(21.3 \%)$ & $50(27.8 \%)$ & $47(17.8 \%)$ & $97(21.8 \%)$ & $27(24.3 \%)$ & $70(20.5 \%)$ & $97(21.5 \%)$ \\
\hline $11 \mathrm{~K}-18 \mathrm{~K}$ & $5(15.6 \%)$ & $8(11 \%)$ & $37(24 \%)$ & $36(20.2 \%)$ & $7(14.9 \%)$ & $93(19.2 \%)$ & $36(20 \%)$ & $49(18.6 \%)$ & $85(19.1 \%)$ & $19(17.1 \%)$ & $69(20.2 \%)$ & $88(19.5 \%)$ \\
\hline $18 \mathrm{~K}-25 \mathrm{~K}$ & $3(9.4 \%)$ & $8(11 \%)$ & $7(4.5 \%)$ & $17(9.6 \%)$ & $9(19.1 \%)$ & $44(9.1 \%)$ & $17(9.4 \%)$ & $21(8 \%)$ & $38(8.6 \%)$ & $14(12.6 \%)$ & $28(8.2 \%)$ & $42(9.3 \%)$ \\
\hline $25 \mathrm{~K}$ and up & $1(3.1 \%)$ & $3(4.1 \%)$ & $8(5.2 \%)$ & $10(5.6 \%)$ & $4(8.5 \%)$ & $26(5.4 \%)$ & $11(6.1 \%)$ & $12(4.5 \%)$ & $23(5.2 \%)$ & $6(5.4 \%)$ & $16(4.7 \%)$ & $22(4.9 \%)$ \\
\hline $\begin{array}{l}\text { Total/\% of } \\
\text { total }\end{array}$ & $35(6.5 \%)$ & $77(14.3 \%)$ & $176(32.6 \%)$ & $201(37.2 \%)$ & $51(9.4 \%)$ & $540(100 \%)$ & $200(40.3 \%)$ & $296(59.7 \%)$ & $496(100 \%)$ & $121(24 \%)$ & $384(76 \%)$ & $505(100 \%)$ \\
\hline
\end{tabular}

\section{Endnotes:}

1 -The abbreviation WCIOM refers to All-Russian Center of Public Opinion Research

2 - The abbreviation INDEM refers to Information Science for Democracy

3 -The abbreviation FOM refers to Fund of Public Opinion

4 -The Russian national average is $9.4 \%$ for 2011 and $18.3 \%$ for 2001 according to the State Committee of Statistics www.gks.ru

5 - In the Volgograd region $15.4 \%$ of populations' income is derived from the entrepreneurship (16.4\% nation-wide), 33\% from hired employees' salary

Police Practice and Research, Vol. 17, No. 3 (June 2016): pg. 229-248. DOI. This article is @ Taylor \& Francis (Routledge) and permission has been granted for this version to appear in e-Publications@Marquette. Taylor \& Francis (Routledge) does not grant permission for this article to be further copied/distributed or hosted elsewhere without the express permission from Taylor \& Francis (Routledge). 
NOT THE PUBLISHED VERSION; this is the author's final, peer-reviewed manuscript. The published version may be accessed by following the link in the citation at the bottom of the page.

(40.6\% nation-wide), $21.4 \%$ from welfare payments $(17.8 \%)$ and $5.4 \%$ from real estate income (6.3\% nation-wide).

6 - also see www.levada.ru for more details

7 -On further discussion of construct validity for procedural justice variables see Reisig et al (2007)

8 - The monthly income is measured in Russian rubles. The currency rate is approximately $\$ 1$ to 30 Russian rubles at the time of data collection

Police Practice and Research, Vol. 17, No. 3 (June 2016): pg. 229-248. DOI. This article is (C Taylor \& Francis (Routledge) and permission has been granted for this version to appear in e-Publications@Marquette. Taylor \& Francis (Routledge) does not grant permission for this article to be further copied/distributed or hosted elsewhere without the express permission from Taylor \& Francis (Routledge). 